\title{
India's Counter-Terrorism Policy against Jihadist Terror: Challenges and Prospects
}

\section{Vinay Kaura}

Sardar Patel University of Police, Security, and Criminal Justice, Rajasthan, India https://www.policeuniversity.ac.in/

\begin{abstract}
The nature of the jihadist terrorism in India is changing as radicalization and recruitment become more sophisticated. There are fears that India may become a soft target in the global jihadist plan of al-Qaeda and the ISIS, which are not only instigating violence through sleeper cells, but are also attracting educated Muslim youths through the Internet to spread their terror agenda while exploiting local grievances. To fight the rapidly changing threat of jihadist terrorism, India needs a comprehensive and innovative approach, rooted in a long-term strategic planning framework and coordinating intelligence, physical security, investigation and crisis management capabilities.
\end{abstract}

Keywords: Jihadist terrorism, Jammu \& Kashmir, counterterrorism, comprehensive approach, intelligence, coordination, strategic planning.

\section{Introduction}

India has been facing several internal threats since its independence from Britain in 1947. The oldest and still unsolved violent struggle against the Indian state has been raging in the Northeast part of the country. But an unsettled sub-nationalist ethnic insurgency in India's Muslim-majority state of Jammu and Kashmir and the growing radicalization of a small but significant segment of the Muslim community in the country have emerged as biggest challenges for India's security. The nature of jihadist terrorism in India has undergone profound changes since the last two decades. Originally supported by Pakistan and confined to a specific territory in Indian-administered Kashmir, it has now become more defused with no specific area. In recent years, cities such as Mumbai, Bangalore, Hyderabad 
and New Delhi have been targets of terrorist attacks. This makes facing the challenge and targeting of jihadist terrorists much more difficult than before.

\section{Changing Nature of Jihadist Terrorism}

With passage of time and the evolution of technology, the operational methodology of terrorists has evolved. Two crucial aspects need attention. First, the terrorism in Jammu \& Kashmir (J\&K) in the previous phase was started by disenchanted Kashmiri youths before the movement was hijacked by Pakistan as part of its low intensity war with India. In the present phase, J\&K is confronted with terrorism predominantly handled by Pakistan's security establishment, either directly or indirectly through anti-India terror outfits such as Lashkar-e-Taiba, Jaish-e-Mohammad and Indian Mujahideen. The firepower of terrorists has also increased tremendously, partly due to the increased resource flow from across the border.

Second, the jihadist terrorism in India is on the verge of acquiring a global footprint, as radicalization and recruitment have become more sophisticated, thanks to social media and Internet. This marks a clear departure from the past when Jihadist terrorism was almost synonymous with the conflict in Kashmir. Most of the groups operating in Kashmir kept their activities confined to that theater except for sporadic incidents in other parts of the country. It was often held that ideologically motivated Islamist-Jihadist terror had bypassed mainland Indian Muslims and that even though there had been a separatist insurgency in the Jammu and Kashmir, Muslims in the rest of India had spurned the radical revivalist movements plaguing other Islamic countries. This is no longer the case.

It is feared that India may become a soft target in the global jihadist plan of outfits such as al-Qaeda and the ISIS, which are not only instigating violence through sleeper cells, but are also attracting educated Muslim youths through the Internet to spread their terror agenda. Though ISIS has declared its intention to expand its footprint in the Indian subcontinent, ${ }^{1}$ it has not managed to make considerable headway in India. However, it is also an undeniable fact that a few of India's misguided Muslim youth are getting swayed by the Wahhabist propaganda. What has been most surprising is that many of the individuals arrested for involvement in some recent attacks are young men with good education and prestigious occupations, such as doctors and engineers. These men are often motivated through the Internet or through Pakistan-based terrorist networks. The majority of the homegrown terrorists are apparently self-radicalized, selfmotivated and inspired by the jihadist ideology of al-Qaeda and ISIS as well as by local grievances. The groups formed to carry out the attacks are loose conglomerations, and it is still unclear whether there is an overarching commanding element directing the different cells.

1 Husain Haqqani, "Prophecy and the Jihad in the Indian Subcontinent," Current Trends in Islamist Ideology 18 (May 2015): 5-17, https://www.hudson.org/research/11310current-trends-in-islamist-ideology-volume-18. 
To fight this fast-changing threat from the hybrid nature of jihadist terrorism, India requires a comprehensive, innovative and coordinated approach. But the central problem that aggravates India's national security policy is the absence of long-term strategic planning. Successive Indian governments have proved unable to formulate an adequate response to the challenge, which has increased the burden on India's security system, particularly its police and intelligence agencies. The internal security mechanism seems unprepared against the jihadist onslaught because of lack of political will and limited operational capacity of police and intelligence organizations.

Intelligence, physical security, coordination among agencies, investigation and crisis management are considered the most important components of counterterrorism activity. If the intelligence apparatus fails to provide early warning about an act of terrorism, the physical security machinery should be able to prevent the terrorists. And if both the intelligence and the physical security mechanisms fail, crisis management should be effective enough to cope with the consequences. ${ }^{2}$ Not much data is available in the open domain about the lapses, however guarded analysis of some previous terrorist attacks indicates that intelligence, physical security, and the crisis management apparatus in India have not performed commendably. After each major terrorist attack, there are emotional demands to know how this can happen despite India's long experience in countering terrorism and insurgency in various parts of the country. In fact, India's institutional capabilities to counter terrorism have remained frozen, or have been augmented by tiny fractions of what is actually required. Even the current regime of Prime Minister Narendra Modi, which has emphasized the need for a robust security policy, has dithered on key security sector reforms. Many crucial projects relating to internal security continue to languish.

\section{National Security Architecture}

There are two styles of counterterrorist activities: a criminal justice counterterrorism, which deals with acts of terrorism within a law-enforcement framework, and a militaristic counterterrorism, which views terror as a threat to national security to be countered with armed force. India has resorted to a combination of both styles in its counterterrorism efforts.

Because of the very size of India and its heterogeneous character, the Indian Constitution has included a distribution of powers between the central government and the state governments; maintenance of law and order is a state subject. However, the federal nature of Indian polity complicates the structures

2 Fred R. Schreier, "Combating Terrorism and Its Implications for Intelligence," in Combating Terrorism and Its Implications for the Security Sector, ed. Theodor H. Winkler, Anja H. Ebnöther, and Mats B. Hansson (Stockholm: Swedish National Defence College, 2005): 129-166, quote on p. 158; A Case for Intelligence Reforms in India, IDSA Task Force Report (New Delhi: Institute for Defence Studies and Analyses, 2012), p. 22, https://www.idsa.in/system/files/book/book_IntellegenceReform.pdf. 
needed for counter-terrorism. Given these problems, India's performance in policing terrorism has been mixed.

Despite constitutional provisions, the Central government has raised seven Central Paramilitary Forces (CPMFs) which are regularly deployed for law and order duties along with the police forces of respective states. ${ }^{3}$ These seven CPMFs are the Central Research Police Force (CRPF), Border Security Force (BSF), Assam Rifles, Central Industrial Security Force (CISF), Indo-Tibetan Border Police (ITBP), Seema Surksha Bal (SSB), and the National Security Guard (NSG), founded in 1986 in the aftermath of Operation Blue Star. While the Indian army has about 1.2 million personnel, all seven CPMFs number more than 1.3 million. CRPF, the most important of the CPMFs, performs a wide range of duties including management of law and order, counter-insurgency and counter-terrorism all over India. Though the BSF and the ITBP are primarily meant for border security, they play a crucial role in counter-insurgency and counter-terrorism operations in three critical conflict-zones - the north-east, Maoist-affected areas, and Kashmir.

The Intelligence Bureau (IB), India's main intelligence agency, functions under the Ministry of Home Affairs and is responsible for internal security and intelligence needs. The IB is considered the nodal counter-terror agency and works closely with the State police and the central paramilitary forces on counter-terrorism intelligence. But it cannot fully execute this function because it has no legal authority to investigate an offence, arrest anyone or prosecute people in court. The Research \& Analysis Wing (R\&AW), India's premier external intelligence agency, operates under the Cabinet Secretariat and, thus, reports to the Prime Minister. It is generally believed that rivalries between the IB and the R\&AW hamper overall intelligence effectiveness. ${ }^{4}$ Other intelligence agencies, such as the Central Economic Intelligence Bureau and the Directorate General of Military Intelligence also perform counter terror functions as part of their organizational mandate.

Following the Kargil incursion by Pakistan in 1999, the government of India carried out a thorough review and reform of India's intelligence apparatus in particular, and the national security system in general. Based on the recommendations of a Special Task Force, the government set up a revamped national security mechanism. The main features of the new mechanism include the creation of a National Security Council (NSC) chaired by the Prime Minister and consisting of a few cabinet members to discuss national security issues; a Strategic Policy Group (SPG) headed by the Cabinet Secretary and comprising the professional heads of the Ministries concerned with national security as well as the heads of the intelligence agencies and the armed forces to work out policy options and submit them to the NSC for consideration; a National Security Advisory Board

3 For a critical profile of India's central paramilitary forces, see K.S. Subramanian, Political Violence and the Police in India (New Delhi: Sage Publications, 2007), 105-124.

4 Prem Mahadevan, The Politics of Counterterrorism in India: Strategic Intelligence and National Security (New York: IB Tauris, 2012). 
(NSAB) consisting of non-governmental experts to provide policy inputs to the National Security Council Secretariat (NSCS), which was set up to service the work of the NSAB, the SPG and NSC; and the creation of a National Security Advisor (NSA) to oversee the functioning of the new mechanism and to advise the Prime Minister on national security issues. The Joint Intelligence Committee (JIC), now a part of the NSCS, coordinates the intelligence inputs at the national level from all intelligence agencies and presents its independent analysis to the Cabinet Committee on Security (CCS). The Defense Intelligence Agency (DIA), started in 2002 as a nodal point to coordinate the activities of Army, Navy and Air Force Intelligence, complements the work of the R\&AW. ${ }^{5}$ After the 26/11 Mumbai attack, India's counter-terrorism architecture has been revamped with the creation of the National Investigation Agency (NIA) to improve investigation capabilities. Deployment of the National Security Guard (NSG) has also been decentralized with four NSG hubs coming into being in different parts of India. The NSG has now matured strikingly as a terror-fighting agency. The amended Unlawful Activities Prevention Act (UAPA) has given new powers to the security agencies, including the ability to hold terror suspects for six months without charges.

Given the complexities involved in India's national security architecture, it is very important to improve coordination between various federal and state security agencies. Post-Mumbai attacks, the first step in this direction was the strengthening of the existing Multi-Agency Center (MAC), an intelligence-sharing 'fusion center' created within the IB in 2002 in the aftermath of the 1999 Kargil conflict. The national MAC coordinates across around two dozen representatives from the intelligence agencies in the home, finance and defense ministries.

The major connectivity in terms of intelligence sharing between the Center and states comes about through the state offices of the IB, and through the newly created Subsidiary Multi-Agency Centers (SMACS) as well as through the connectivity between the SMACS and state police Special Branches. It is another matter that personnel shortages have hindered their efficacy and in practice they function as little more than state-level IB offices. In a sign of the fundamental weakness of many of India's state police services, most of the intelligence inputs into the MAC come from a handful of states. Moreover, due to constitutional provisions, the intelligence sharing mechanism exists according to the goodwill of the states; if a state is not willing to cooperate with the central government, it cannot be forced to do so. Each agency guards its own turf, and coordination mostly depends on the interpersonal relationships between the officials of the agencies. ${ }^{6}$

5 Behram A. Sahukar, "Intelligence and Defence Cooperation in India," in Intelligence Cooperation Practices in the 21st Century: Towards a Culture of Sharing, ed. Musa Tuzuner (Amsterdam: IOS Press, 2010), 31-41.

6 For a review of India's security reforms after the Mumbai attacks, see Sarah J. Watson and C. Christine Fair, "India's Stalled Internal Security Reforms," India Review 12, no. 4 (2013): 280-299. 
Due to this ad-hoc process and because of India's federal structure, the current national security architecture in general and the counter-terrorism structure in particular is flawed as there is no single authority from which these agencies receive unified directions.

\section{Controversy over Anti-Terror Laws}

Policing terrorism in India is fraught with numerous difficulties. The legal structure, inherited from the colonial past, has been struggling to cope with the demands placed upon it. As mentioned in the previous section, a number of police, intelligence and military organizations contribute to counter-terrorism efforts. India's Ministry of Home Affairs oversees national police, domestic intelligence and paramilitary forces. The major legislation to deal with terrorism in India is the UAPA. Some Indian states such as Maharashtra and Karnataka have their own laws which are used to prosecute suspected terrorists. The Terrorist and Disruptive Activities (Prevention) Act (TADA), the first anti-terrorism law to define and counter terrorist activities, was allowed to lapse in $1995 .^{7}$ When there were several allegations of misuse in the application of the new anti-terror law, the Prevention of Terrorism Act (POTA), it was decided to repeal the act in 2004. This was followed by an amendment to the already existing UAPA. India's experiments with TADA, POTA and UAPA have failed to deliver the desired results. There have been allegations that the anti-terror laws are designed to shield or harass a particular community or religious denomination. The Second Administrative Reforms Commission (ARC) of India opined in its report in 2008 that "a comprehensive and effective legal framework to deal with all aspects of terrorism needs to be enacted. The law should have adequate safeguards to prevent its misuse." 8

\section{Failed Attempt to Create NCTC}

The sweeping internal security reforms initiated after the Mumbai attacks were followed, a year later, by the announcement of central government's intention to create a National Counter Terrorism Center (NCTC) and a national computerized information-sharing network, known as the NATGRID. But the greatest failure of the post-Mumbai reforms was the NCTC, which was supposed to be established within a year of its announcement in December 2012. The central government's efforts to set up the NCTC-whose aim included preventing, containing and responding to a terrorist attack-were trapped in the political quagmire of Center-State relations and the intended launch of the NCTC had to be put on

7 "The Terrorist and Disruptive Activities (Prevention) Act, 1987," Act No. 28 of 1987, amended by Act 43 of 1993, available at the South Asia Terrorism Portal, www.satp.org/satporgtp/countries/india/document/actandordinances/tada.htm.

8 Combating Terrorism: Protecting by Righteousness, Eighth Report of the Second Administrative Reforms Commission (New Delhi: Government of India, June 2008), https://darpg.gov.in/sites/default/files/combating_terrorism8.pdf. 
hold. Non-Congress ruling states of Gujarat, Tamil Nadu, Odisha, Karnataka, Bihar, Tripura and West Bengal were opposed to the proposal; their main contention was that the NCTC would violate the principle of federalism. As per Indian Constitution, 'public order' and 'police' are in the State List, which is sole preserve of a state government.

The NCTC was conceived as the centerpiece of internal security reforms. It was modeled on the American institution of the same name, which functions as a center for joint operational planning and joint intelligence. India's NCTC, which was meant to subsume the MAC and whose operatives would have arrest powers throughout India, encountered a storm of criticism from State governments, who expressed strong concerns about the new agency being given the powers of arrest and searches without the prior knowledge of the state police. Similarly, the civil liberties activists saw the move as an unconstitutional expansion of government control. In the face of state opposition, plans for the NCTC were steadily watered-down: first the operational wing was eliminated, and then the NCTC as a whole was placed under the control of the Intelligence Bureau.

The states which opposed the NCTC cited two primary reasons for their opposition to it: clause 3.2 and the enabling section 43A of the UAPA, which authorized NCTC to arrest any suspect and to carry out operations without prior approval from and knowledge of the respective states; and clause 3.5, under which the NCTC would "have the power to seek information, including documents, reports, transcripts, and cyber information from any agency" in order to carry out its functions. ${ }^{9}$ In wanting to emulate the US model, the Home Ministry had overlooked a significant detail: the US NCTC is part of its Directorate of National Intelligence (DNI), which is manned by officials from the Pentagon, $\mathrm{FBI}, \mathrm{CIA}$ and other agencies who can access its databases. The Center analyzes and collates terrorism related information to support counterterrorism operations of intelligence agencies. It is not authorized to conduct intelligence operations on its own and it has no powers to investigate or arrest. ${ }^{10}$

The Intelligence Bureau's control over NCTC also became a major bone of contention. It is commonly accepted principle in all liberal democratic countries that an intelligence agency should not possess police powers of arrest. Opposition parties expressed fear that if NCTC is made part of IB, the powers given to it under the UAPA could be misused. Presently IB is practically immune from any parliamentary oversight and its lack of parliamentary accountability would be further perpetuated by NCTC. ${ }^{11}$ The gross politicization of India's intelligence

9 Sameer Patil, "Counter-Terrorism and Federalism," Gateway House (Indian Council on Global Relations, August 14, 2014), www.gatewayhouse.in/counter-terrorism-andfederalism/.

10 P.R. Chari, "National Counter Terrorism Centre for India: Understanding the Debate," IPCS Issue Brief 181 (New Delhi: Institute of Peace and Conflict Studies, March 2012), https://www.jstor.org/stable/resrep09133.

11 Josy Joseph, "Locating NCTC Within Intelligence Bureau or Not: The Debate Continues," Times of India, July 17, 2012, https://timesofindia.indiatimes.com/india/ 
agencies has allowed the ruling parties to use these agencies to monitor the activities of the leaders of opposition parties and harass them. For instance, Bihar Chief Minister, Nitish Kumar, had opposed the proposed structure of NCTC on the ground that it was to be "created within the Intelligence Bureau which is a secret intelligence organization without any accountability to Parliament or the court". ${ }^{12}$ One should also not forget that there were several allegations that the NIA was used by the previous UPA government for political purposes to probe right-wing terror cases such as the 2006 Malegaon blasts and the 2007 Samjhauta Express bombings.

Second, the turf war between different intelligence agencies operating under different government ministries also caused problem for the establishment of NCTC. In fact, the Union Home Ministry committed the mistake by making the NCTC a part of the IB, rather than an independent institution. According to B. Raman, a former top official of the R\&AW, "there were inadequate consultations even at the center as one could see from the opposition expressed by an increasing number of ex-R\&AW officers to the move to make the NCTC a part of the IB." ${ }^{13}$ Third, there have been several accusations of the alleged biases in the security agencies against the minority communities, particularly during counter terror operations.

Other internal security reforms have met with mixed success. The NATGRID was originally envisioned as a unified database that would compile a wide variety of currently available intelligence inputs. NATGRID has acquired some of the world's most advanced data-mining software that can be used to track and potentially predict terrorist attacks. The system has faced internal resistance, however, particularly from the IB, which feels that NATGRID is encroaching on its turf. ${ }^{14}$ More than eight years after 26/11, NATGRID is still being spoken of as being in an 'embryonic stage.' Some of the features of NATGRID will be replicated by the Crime and Criminal Tracking Networks \& System (CCTNS), which is meant to seamlessly link India's more than 14,000 police stations to allow for better information-sharing. Several years later and despite a budget of millions of dollars, what "the government has to show for itself are a mess of reports, proposals, committees, red tape, turf battles, and the mirage of a robust security architecture." ${ }^{15}$ After struggling with several problems, it has been decided to complete the implementation of the project by March 2017. The National Inves-

Locating-NCTC-within-Intelligence-Bureau-or-not-The-debatecontinues/articleshow/15011283.cms.

12 "NCTC Flouts 'Sacrosanct' Tenet: Nitish," The Telegraph, May 6, 2012, available at https://www.telegraphindia.com/1120506/jsp/bihar/story_15456246.jsp.

13 B. Raman, "The NCTC Controversy," Outlook, March 5, 2012, available at http://www.outlookindia.com/article.aspx?280150.

14 Sandeep Unnithan, "Anti-Terror Grid in Deep Freeze," India Today, November 25, 2015, available at https://www.indiatoday.in/magazine/nation/story/20151207-antiterror-grid-in-deep-freeze-820885-2015-11-25.

15 Unnithan, "Anti-terror Grid in Deep Freeze." 
tigation Agency (NIA) has also faced backlash from the states, which resist giving up their jurisdiction over policing. But the central government continues to push to make it the leading national agency.

\section{Police incapacity}

The Mumbai terrorist attack of 2008 and the Pathankot airbase attack of 2016 exposed key vulnerabilities in India's defenses against terrorism. Not only did they reflect a remarkable degree of sophistication on the part of jihadist planners, but the attacks demonstrated that the India's policing system was woefully inadequate for the task of combating suicidal assaults. Ajai Sahni, executive director of the Institute of Conflict Management, cannot be more correct when he argues that Indians "can't have first-rate counter-terrorism in a third-grade policing system." Praveen Swami, one of India's leading journalists having extensive knowledge of terrorism, echoes Sahni's argument when he observes that "Policing is the front line of a counterterrorism response; India's front line has disintegrated." 16

Internal security faces added challenges with a poorly trained and understaffed police force, and insufficient modern equipment at their disposal. There is considerable variation in the size and competence of India's various State police forces. But India's low police-to-population ratio of about 180 per 100,000 is much lower of what the United Nations has recommended for peacetime policing. In Western countries, the police-to-population ratio ranges from 250 to 500 per 100,000. According to India's Bureau of Police Research \& Development (BPRD), $24 \%$ of posts in the police forces nationwide are lying vacant, with the State of Uttar Pradesh having the largest number of vacancies where only 181,000 police personnel are employed against the sanctioned strength of $363,000 .{ }^{17}$ Moreover, because of India's notorious and pervasive VIP culture, the number of police personnel actually available for the security of the common citizen is very dismal. Only one cop is available for the security of 729 Indian people, leaving police personnel overburdened and overstrained. ${ }^{18}$ Given the acute shortage in their ranks, police personnel are required to work long hours without a break and rarely get to take even their weekend off, leaving them stressed and frustrated. This has a huge bearing on their professional responsibilities, including counterterrorism duties.

16 Praveen Swami, "A Decade After 9/11, Indian Jihad Still Thrives," The Hindu, September 9, 2011, https://www.thehindu.com/opinion/lead/a-decade-after-911-indianjihad-still-thrives/article2439813.ece.

$17 \mathrm{PTI}$, "50 pc of Police Posts Vacant in UP; National Average at 24 pc," India Today, April 2, 2017, https://www.indiatoday.in/pti-feed/story/50-pc-of-police-posts-vacant-inup-national-average-at-24-pc-900731-2017-04-02.

18 "Shortage of Police Personnel Alarming," Deccan Herald, February 16, 2017, available at https://www.deccanherald.com/content/596749/shortage-police-personnelalarming.html. 
Police in India are trained and mentally conditioned to deal with law and order problems. When faced with terrorism and insurgency, they find it extremely hard to respond effectively. To successfully prevent terrorism, the public must be willing to share with the police any vital information or suspicious activity in their locality, but even after 70 years of country's independence, the basic character and image of Indian police have not undergone any significant change. The police are held in low esteem and they are more often viewed with suspicion. Political interference in the functioning of the police, which has become a norm, leads to the abuse of authority by the police. Regrettably, many police officers deliberately allow their professional autonomy to be dominated by political pressures in their own anxiety to please the political masters. The most undesirable fallout of political interference in police functioning is the decline in its ability to respond effectively to difficult and violent situations. Ved Marvah, a former Indian Police Service officer and former governor of Manipur, Mizoram and Jharkhand, is straightforward in claiming that when state governments are reluctant or fail to deal with violent conflicts and anti-national movements, "instead of strengthening the state police machinery, it rushes to the Centre to hand over its responsibility at the first sign of any serious trouble. It is not surprising that in these states some sections of the police have actually joined hands with the subversive forces against the central forces." ${ }^{19}$

Corruption in the police also aggravates the challenge of fighting terrorism as there is a close relationship between crime, corruption and terrorism in the Indian context. For instance, criminal gangs such as ' $D$ Company' have widespread networks for smuggling purposes, involving agents of corruption in the police and customs. Moreover, politicians have a leading role in manipulating the police for negative intentions or at least they turn a blind eye when police remain inactive in the face of communal disorders.

In 2006, the Supreme Court of India in a landmark judgment ordered the central and state governments to implement some crucial police reforms. From the standpoint of strengthening internal security, the most important order relates to the separation of the investigation and law and order functions of the police. Besides, the order to setup the State Security Commission is mainly directed to ensure that the state government does not exercise unnecessary influence or pressure on the police. But state governments have displayed absolute indifference to the Court order. ${ }^{20}$ The reasons are not hard to find. The police are not insulated from partisan politics because the government does not allow the police to develop into an efficient and effective service. All governments want the police to behave "as the armed wing of their ruling party" as much of the power

19 Ved Marwah, "India's Internal Security Challenges," Strategic Analysis 27, no. 4, (October-December 2003): 503-515.

20 "SC Anguished over States' Indifference to Police Reforms," Zee TV News, July 21, 2009, available at http://zeenews.india.com/news/nation/sc-anguished-over-statesindifference-to-police-reforms_549020.html. 
of the executive in a post-colonial system like India is derived from the control of police.

With police reforms taking a back seat, the command and control systems of the police are also in a state of utter breakdown. The manner in which the police handled the Mumbai terror attacks in November 2008 clearly demonstrates that they are not trained for the task of confronting modern-day terrorism. The attack manifestly revealed the catastrophic weaknesses in Indian's police and intelligence apparatus. The Mumbai police did a poor job, not only due to a lack of nerve on the part of their top leaders, but also because of poor command and control. The Mumbai Police Commissioner "did not take charge of the situation and allowed all and sundry to jump into the fray and create a chaotic situation." 21 The failure of intelligence agencies to anticipate major terror attacks including the Mumbai terror attacks of 2008 and "to apprehend most of those responsible over the years, speaks not just to weak, under-motivated, and under-equipped police forces but also to dubious intelligence capabilities."22

India's former Prime Minister Manmohan Singh had underlined the importance of state police and intelligence agencies in the fight against terrorism, when he pointed out in September 2006, that "Unless the beat constable is brought into the vortex of our counter-terrorist strategy, our capacity to preempt future attacks would be severely limited." ${ }^{23}$ Prime Minister Narendra Modi, at the Guwahati Conference of the Directors General of Police of states in November 2014, enunciated the concept of SMART Police - a police which should be sensitive, mobile, alert, reliable and techno-savvy. ${ }^{24}$ However, there has hardly been any progress in that direction because not much has been done to either insulate the police from extraneous influences or to improve the orientation and operational capacity of the policemen themselves.

\section{Twin Jihadist Challenges}

The Pathankot airbase attack in January 2016, which exposed key vulnerabilities in India's defenses against terrorism, is the latest example of the continuance of India's weak national security decision making process, porous borders, limited law enforcement capabilities and political expediency. Seven security personnel

21 Ved Marwah, "The Role of India's Police in Combating Terrorism," in Combating Terrorism, ed. Maroof Raza (New Delhi: Viking, 2009), 80-97, quote on p. 83.

22 David Malone and Rohan Mukherjee, "Polity, Security, and Foreign Policy in Contemporary India," in South Asia's Weak States: Understanding the Regional Insecurity Predicament, ed. T. V. Paul (Stanford, CA: Stanford University Press, 2010), 147-169, quote on p. 160.

23 See for example Ajit Kumar Singh, "Tuning the Indian Police," Geopolitics 2, no. 6 (November 2011): 54-55, quote on p. 55.

24 "PM's address at the All India Conference of Directors General/Inspectors General of Police," PMINDIA - Official website of India's Prime Minister, November 30, 2014, www.pmindia.gov.in/en/news_updates/pms-address-at-the-all-india-conference-ofdirectors-generalinspectors-general-of-police-2. 
were killed in the attack that lasted more than 72 hours. The attack demonstrated that the Indian policing system continues to remain woefully inadequate for the task of combating suicidal terror assaults, while confirming the widelyheld perception that the country has not learnt much after the horrendous Mumbai terror attack of 2008. Similarly, the terrorist attack at an Indian army's brigade headquarters in the border town of Uri in Jammu and Kashmir in September 2016 again highlighted the threat India faces from cross-border terrorism. The attack, which claimed the lives of 19 Indian soldiers, was one of the biggest psychological and strategic blows to Indian security forces in Jammu and Kashmir. Although the Indian government carried out 'surgical strikes' against terrorist launching pads across the Line of Control (LoC) in Pakistan-administered Kashmir a few days after the attack in September 2016, ${ }^{25}$ this counterattack has not been able to deter the Pakistan-based terrorists from indulging in cross-border terrorism.

Ajay Sahni has sarcastically noted that "if this is the state of protection of major national strategic assets, the preparedness-or rather, unpreparednessacross the rest of the country can only be imagined ... An examination of the security apparatus in the country, however, leads one to wonder why the attacks have been so few and relatively ineffective ... We have, moreover, been fortunate that the terrorists in this country have yet to adopt the even more devastating tactics, materials and technologies that are being used in other theatres of terrorism across the world." 26 The Parliamentary Standing Committee on Home Affairs, which investigated the Pathankot terror attack, has wondered why the Jaish-e-Mohammad terrorists let go a senior Punjab Police officer after waylaying his official vehicle and using it to reach the Pathankot airbase in January 2016. The multi-party committee, headed by the former Union home minister $P$ Chidambaram, has lambasted the functioning of Punjab Police, while also asking many uncomfortable questions about the role played by the National Investigation Agency (NIA). ${ }^{27}$ India's state of Punjab witnessed two terror attacks in the space of six months, first at Dinanagar in Gurdaspur district in July 2015, followed by Pathankot in January 2016.

To compound the challenge emanating from Pakistan-based jihadist outfits, there are many Indian Muslim youths who are estimated to be fighting for ISIS

25 Manjeet Singh Negi, "Surgical Strikes in PoK: How Indian Para Commandos Killed 50 Terrorists, Hit 7 Camps," India Today, September 29, 2016, available at http://indiatoday.intoday.in/story/uri-avenged-inside-story-indian-army-surgicalstrikes-pok/1/776433.html; Raj Kumar Arora and Vinay Kaura, "'Surgical Strikes' Beginning of a New Era in Counter-Terrorism in Kashmir?" CPCS Occasional Paper 10 (Jaipur: Center for Peace and Conflict Studies, October 2016).

26 Ajay Sahni, "Pathankot Learnings: India Widely Exposed to Terrorism, Even in Best Protected Locations," The Economic Times, January 10, 2016.

27 Rohan Dua, "House Panel on Pathankot Attack Puts Punjab Police SP Salwinder Singh Under Cloud", The Times of India, February 14, 2017, available at http://timesofindia.indiatimes.com/india/house-panel-on-pathankot-attack-putspunjab-police-sp-salwinder-singh-under-cloud/articleshow/57137279.cms. 
in Iraq and Syria. The IB estimated in 2016 that the Islamic States' Indian cell engaged more than 700 people in conversation and raised more than 20 identified volunteers. ${ }^{28}$ During the last two years, the NIA has made several arrests of persons accused of forming ISIS modules, whose members use online social media platforms for plotting terrorist attacks. ${ }^{29}$ The data suggests that people ideologically subscribing to ISIS are present across India, making it increasingly difficult for the law enforcement agencies to keep track of them. The Minister of State for Home Affairs of the government of India has informed the upper house of parliament that 75 people have been arrested for suspected links to the ISIS terror network. Out of these 75 persons, 21 were arrested from Kerala, 16 from Telangana, 9 from Karnataka, 8 from Maharashtra, 6 from Madhya Pradesh, 4 from Uttarakhand, 3 from Uttar Pradesh, 2 from Rajasthan, 4 from Tamil Nadu and one each from Jammu \& Kashmir and West Bengal. ${ }^{30}$ The NIA has also revealed that it had arrested 52 people for allegedly being ISIS terrorists in 2016, which also included a few converts from Hinduism and Christianity. While releasing data on the arrests, the NIA gave details of the religious affiliations of the accused; 50 percent belong to 'Ahle Hadith,' 30 percent to 'Tabligi Jammat,' and 20 percent followed Deobandi ideology. Out of 34 cases registered by the NIA in 2016, 21 were related to Jihadi terrorism. ${ }^{31}$

Initial investigations into the Bhopal-Ujjain passenger train blast in March 2017, which has been claimed as the first major ISIS operation in India, ${ }^{32}$ have given intelligence agencies a fresh challenge to pursue sympathizers of the global extremist group and track those highly-indoctrinated Indian Muslims that were fighting in Iraq and Syria. Saifullah, the alleged IS-inspired terrorist killed in a shootout with police on March 8, 2017 in Lucknow, had been tasked with securing arms and training facilities for a new Islamic State-linked cell in Uttar Pra-

28 Praveen Swami, "For ISIS, Virtual is the Real as It Scouts for India Recruits," The Indian Express, March 22, 2016, available at https://indianexpress.com/article/india/indianews-india/for-isis-virtual-is-the-real-as-it-scouts-for-india-recruits/.

29 K. K. Abdul Rahoof, "NIA Busts ISIS Terror Module in Hyderabad; 11 Suspects in Custody," Deccan Chronicle, June 30, 2016, https://www.deccanchronicle.com/nation/ current-affairs/300616/nia-nabs-11-isis-terrorists-in-hyderabad.html; Shweta Desai, "Hyderabad Men's Pledge Shows Close Knowledge of Islamic State Group," Daily News and Analysis, December 26, 2016, www.dnaindia.com/india/report-hyderabad-mens-bayah-shows-close-knowledge-of-is-group-2286478.

30 "75 Arrested for Alleged Links with ISIS: Govt," Press Trust of India (PTI), March 15, 2017, http://www.ptinews.com/news/8503038_75-arrested-for-alleged-links-withISIS--Govt.html.

31 PTI, "Converted Hindus, Engineers among 52 ISIS Terrorists Held by NIA," The Indian Express, January 19, 2017.

32 Punya Priya Mitra, "ISIS Module Behind Blast in Bhopal-Ujjain Passenger Train in Madhya Pradesh, Police Say," The Hindustan Times, March 8, 2017, https://www.hindustantimes.com/india-news/isis-module-behind-blast-in-bhopalujjain-passenger-train-in-madhya-pradesh-police-say/storyc0jKbjwKCOqa4xb2kIfQVO.html. 
desh. ${ }^{33}$ The NIA first came to know of Saifullah from Mudabbir Mushtaq Sheikh, a resident of the State of Maharashtra. Mudabbir is now facing trial for his role as chief of the Jund-ul-Khalifa-ul-Hind (army of the Caliph in India), an organization of Indian jihadists inspired by ISIS. ${ }^{34}$

Indian agencies are reportedly worried on three accounts: first, a 'lone actor' attack, similar to some recent attacks in many European cities; second, presence of distinct terror cells which can be activated at short notice; and third, radicalized youth approaching other terror organizations for logistical support. Because of these factors, ISIS is being viewed as posing a serious security threat as its ideologues are not part of an organized group. By comparison, the Indian Mujahedeen (IM) was relatively easy to crack, because one arrested individual would "spill the beans" on other members. ISIS is a different phenomenon as every cell is different and is being handled by different operators abroad. ${ }^{35}$ As ISIS has been routed in Iraq and Syria and their members are on the run, another worry of security agencies concerns their return to India.

\section{Recommendations}

The optimal functioning of India's state institutions gets often compromised by poor functioning of institutional structures. The key lies in strengthening governing institutions at the state level, establishing the rule of law on a firm footing and providing a sense of dignity and security to its citizens.

- There is a need to make the National Security Council (NSC) a more professional and effective body, so that it can work in an optimal manner by anticipating national security threats and developing a coherent strategy to deal with them.

- Whilst intelligence should be the primary strategic consideration for addressing terrorism, it can only be effective if delivered in such a manner that meets the needs of its customers. In the age of jihadist terrorism, the characteristic of sound intelligence is the ability to fuse the intelligence gathered at the grassroots level with that analyzed at the national levels - what has become known in the US as 'connecting the dots.' The government should decide soon whether the required mechanism should be embedded in the existing agencies or in the establishment of a National Counter-Terrorism Center (NCTC) incorporating the functions being performed presently by the MAC and JIC.

33 Praveen Swami, "Train Suspect Shot Dead Was Named Last Year by Member of ISInspired Cell, Police Lost Trail," The Indian Express, March 9, 2017.

34 Swami, "Train Suspect Shot Dead."

35 Sahil Makkar, "NIA chase, hawala and recruits: India turns into fertile ground for ISIS," Business Standard, March 27, 2017, available at https://www.businessstandard.com/article/current-affairs/nia-chase-hawala-and-recruits-india-turns-intofertile-ground-for-isis-117032500782_1.html. 
- $\quad$ The US established its Department of Homeland Security after 9/11. In India the need for the establishment of a separate Ministry of Internal Security has been felt for a long time, but this proposal continues to languish. The government should create this ministry and the NCTC should be placed under this new Ministry.

- $\quad$ The police are the first responders in the event of any terrorist attack. They are also the backbone of India's intelligence, investigation and anti-corruption agencies. For the security of the common citizen and to deal with the major threats confronting the country, India needs to have a reformed and restructured police force. Thus, the highest priority needs to be accorded to improving the profile of an average policeman at the grassroots level.

- $\quad$ Every police organization in India has deep-rooted inefficiencies built into existing processes of administration, deployment and operation. Large proportions of them are often wasted in unproductive deployments, without clear objectives within a crime-fighting or counter-terrorism framework. It is necessary to make an objective evaluation of current processes and redeploy the manpower more efficiently. Greater degree of police efficiency will also bring about changes in public perception.

- Given the fact that India is combating several active insurgencies along with countering terrorist attacks launched from inside and outside the country, it is imperative that Indian states increase the size of their police forces. An accelerated recruitment drive to fill all sanctioned posts in the police force should be the highest priority within a time-bound framework. Sanctioned strengths must also be continuously reevaluated in the context of emerging challenges.

- Most people in the security system remain oblivious to the transformations taking place in the field of policing and have little capacity to absorb and adapt to all but the most obvious technological manifestations of these transformations. For instance, India's state police forces are generally poorly trained and lack the ability to collect and analyze forensic evidence in accordance with international standards. Therefore, the training and education of police professionals must be a continuous and intensive process and must be built into the schedule of their responsibilities. Attention must be given to develop domain expertise on crime-fighting and counter-terrorism tactics.

- There are no cyber specialists or information warfare specialists, who would continue to work in their area of specialization after their limited tenures. The paramilitary and the army continue to be led by, what is often referred to as, generalist officers. Even when these officers develop a degree of specialization in the cyber domain, their next appointment often takes precedence over retaining domain expertise. Despite 
having a National Cyber Security Policy since 2013 and a National Cyber Security Coordinator, the overall ecosystem of cyber security in India has not improved much. India must develop cyber security capacity among its security forces.

- The intelligence component of the state police requires greater augmentation. It should have an effective presence in each police station, particularly in the rural areas. Capacities to gather actionable and evidentiary intelligence also need to be developed, so that efficient prosecutions can be launched and convictions secured. Intelligence flows generated through the state police apparatus must interface in real time with the national databases, including MAC and CCTNS.

- India is not a wealthy country. Because of its sheer size and population, India has many pressing needs and the budgetary allocations for the internal security sector reflect India's lack of economic resources. Compared to the budgets of even much smaller developed countries, India cannot provide sufficient money for its security agencies, leading to problems of under-training and under-staffing and often counterproductive policing techniques. International assistance in the form of grants for training and equipping police forces could substantially reduce the burden of this major reform on India's budget. The United States can play a meaningful role in strengthening India's counterterrorism capabilities. One of the traditional strengths of the US law enforcement establishment has been training other countries' police and domestic intelligence agencies. India would benefit enormously from a sustained program bringing Indian police personnel to the US for training, as well as sending American trainers to Indian police academies. This training program would have the broader effect of increasing the professionalism of India's police and paramilitary forces.

- There is an urgent need for increased professionalism among state police personnel. India's Muslim community often perceives local police as biased and brutal. Focusing more on improving relations between the local police and Muslim communities can go a long way in preventing the radicalization of Muslim youth.

- If Indian Muslims, including disgruntled Kashmiri youth, are to be dissuaded from joining the so-called jihad, it is important to find more effective strategies to discredit Islamist radicals both on the battlefield and in cyberspace. The police, the paramilitary forces and the army in Kashmir must assertively employ all available social media platforms as well as all traditional propaganda tools to present an accessible, helpful, efficient and accountable image of themselves. India's security establishment would do well to put less emphasis on a heavy-handed and only tactical response to terrorism-driven insurgency in Kashmir. Given the growing importance of the insurgency's virtual dimension, it is vital 
to frame a 'strategic narrative' - a compelling storyline which can explain the government's side convincingly.

\section{Conclusion}

India's response to terrorism has been largely characterized by ad-hocism, which has often led towards the creation of new agencies, meta-institutional innovations and over-centralization, an illusion of power created by technological acquisitions, and the states abdicating their law and order responsibilities. Political expediency further complicates the problem. The state governments remain preoccupied with their survival in power, which hamper their ability to look at the problem from a long-term perspective.

The internal security system is fragmented and poorly coordinated as there are a multitude of investigative and law enforcement agencies at the center and in the states. State police forces have their own counter-terrorism and intelligence units, which are often weak and work in an isolated manner. There has been an increase in the types and numbers of central paramilitary forces, but the most serious problem is of coordination of their efforts. The central and state agencies do coordinate through loosely defined mechanisms, but these are often found to be slow.

One of the major deficiencies in India's institutional approach to counter-terrorism is the gross divide between how the central and state governments view counter-terrorism. This is the reason why the proposal to create the National Counter-Terrorism Center (NCTC) has not achieved success. India cannot look for any early resolution of the problem of terrorism, either through strong anti-terror legislation or political amelioration of the issues that give rise to terrorism. Terrorism cannot entirely be countered by 'hardening' of possible targets by improving protection. Counter-terrorism activities, to be effective, must be proactive, and this intrinsically involves massive improvements in policing and intelligence - areas which have been terribly neglected. The implications of this neglect have been far-reaching. Whatever gains have been achieved in the fight against terrorism should not be allowed to be compromised or reversed because of inaction.

\section{About the author}

Vinay Kaura, PhD, is an Assistant Professor in the Department of International Affairs and Security Studies at the Sardar Patel University of Police, Security, and Criminal Justice in Rajasthan, India. He is also coordinator at the Center for Peace and Conflict Studies, Jaipur, at the Sardar Patel University of Police, Security and Criminal Justice. His research interests include India's neighborhood policy, especially on the western front, Afghanistan-Pakistan relations, counterterrorism and counter-insurgency, and conflict resolution in Kashmir.

E-mail: vinay@policeuniversity.ac.in. 